\title{
The effect of habitat and number of inhabitants on the population sizes of feral pigeons around towns in northern Poland
}

\author{
Tomasz Hetmański • Marcin Bocheński • \\ Piotr Tryjanowski • Piotr Skórka
}

Received: 29 March 2010 /Revised: 19 September 2010 / Accepted: 21 September 2010 /Published online: 5 October 2010

(C) The Author(s) 2010. This article is published with open access at Springerlink.com

\begin{abstract}
Most studies on factors influencing density of the feral pigeons Columba livia var. domestica were carried out in large cities and agglomerations. However, also in small towns, pigeons are important epidemiological and sanitary problem. In our studies, feral pigeons were censused in 33 towns located in the Pomeranian Province (northern Poland) during 2006-2008. These birds occurred in 19 $(57.6 \%)$ towns. The number of pigeons was positively correlated with the area of the town, and it was significantly higher in towns localized in agricultural landscape than in towns surrounded by forests. We also found a significant effect of interactions between type of a landscape surrounding a town and residual number of inhabitants on the abundance of pigeons. In the largest towns of the
\end{abstract}

Communicated by C. Gortázar

T. Hetmański $(\bowtie)$

Department of Zoology, Pomeranian University,

Arciszewskiego 22b,

76-200 Słupsk, Poland

e-mail: tomek.hetman@wp.pl

M. Bocheński

Department of Nature Conservation,

Faculty of Biological Sciences, University of Zielona Góra,

Prof. Z. Szafrana St. 1,

65-516 Zielona Góra, Poland

e-mail: m.bochenski@wnb.uz.zgora.pl

P. Tryjanowski • P. Skórka

Institute of Zoology, Poznan University of Life Sciences,

Wojska Polskiego St. 71 C,

60-625 Poznań, Poland

P. Tryjanowski

e-mail: piotr.tryjanowski@gmail.com

P. Skórka

e-mail: skorasp@poczta.onet.pl
Pomeranian Province, feral pigeons were concentrated mainly in central quarters. In smaller towns, they were noted in central parts or in areas with blocks of flats and even the suburbs. The obtained results suggest that food conditions in small and middle towns may be not sufficient for colonization by pigeons.

Keywords Columba livia - Distribution - Colonization . Foraging strategy $\cdot$ Urban ecology

\section{Introduction}

Feral pigeons are a great challenge for municipal authorities because they must take care of the health of the people and also of keeping the town clean. These birds, which are abundant in large towns, can be vectors of many diseases of humans and domestic animals. They often naturally infected people of viruses, bacteria, fungi and pathogenic protozoans (Bassi and Chiatante 1976; Haag-Wackernagel and Moch 2004; Vlahović et al. 2004). Moreover, in large towns, they are a source of ornithosis in human by infection of Chlamydophila psittaci (Magnino et al. 2009). The major problem is the harmful effect of pigeon faeces floating in the air as dust that can be breathed in (HaagWackernagel and Moch 2004). Thus, it is obvious that the places where pigeons occur in high densities are dangerous to the health of people. To prevent local concentration of pigeons, pigeon-deterring devices can be used, such as nets or spikes put on buildings (Haag-Wackernagel 2000).

Failure of control programs to capture pigeons is caused by immigration of individuals from nearby populations ( $\mathrm{Sol}$ and Senar 1995). According to Haag-Wackernagel (1993), the effective long-term elimination procedure is the limitation of food supplied by "pigeon lovers". For a successful 
culling of surplus pigeons, it is necessary to understand all factors promoting their reproduction. One of the most important factors is food resources.

Barbieri and De Andreis (1991) found that the population size of feral pigeons depends on the size of a town, but Jokimäki and Suhonen (1998) showed that it also depends on the density of human population. It is well evidenced that urban areas and people living there provide abundant food resources for birds (Jokimäki and Suhonen 1998; Jokimäki and Kaisanlathi-Jokimäki 2003; Marzluff et al. 2001; Fuller et al. 2008; Robb et al. 2008). However, both size of a town and density of human population are often strongly correlated, making it difficult to separate both effects. According to Speirs et al. (1970), the abundance of pigeons does not necessarily depend on the size of human population, and it may be also influenced by the history of the town. Frequent foraging strategy of feral pigeon is to look for food within the town, but urban pigeons can fly longer distances and forage in farmland (Janiga 1987; Rose et al. 2006a). The same foraging strategy is used by rock pigeons Columba livia, which are progenitors of feral pigeons (Baldaccini et al. 2000). In some big cities, pigeons foraging outside of the city areas may constitute a small fraction of the total population, as it was found in Basel where this foraging strategy was demonstrated for ca. $6 \%$ of population (Rose et al. 2006a), but in Milan, it was just up to $46 \%$ (Sacchi et al. 2002). Therefore, foraging in farmland can largely influence population size in towns. If the population size of the feral pigeon depends on availability of the farmland area in the vicinity of the town, then it should be independent of human population size in the town. Otherwise, if the landscape in the vicinity of towns is dominated by forests or wetlands, then population size of the feral pigeons should be strongly dependent on size of human population in towns, as birds may forage only on human-related food resources. In other words, we expect significant interaction between landscape type surrounding the town and number of human inhabitants, i.e. in forested/water landscape, we expect stronger relationship between number of human inhabitants and number of pigeons than in towns surrounded by farmland.

The main aim of this paper was to determine the influence of different parameters such as size of a town, number of human inhabitants and landscape type surrounding towns on numbers of feral pigeons in towns of Pomerania Province (northern Poland). We examined the following predictions: (1) population size of the feral pigeons is positively correlated with the human population size in towns, but (2) population size of the feral pigeons is much more linked with human population size in towns surrounded by forests and water than in towns surrounded by farmland. We also expected (3) that number of pigeons is positively related to the town area.

\section{Materials and methods}

Study area

The distribution and abundance of feral pigeons were examined in 33 towns of northern Poland in the autumn of 2006 and 2008. The study area is presented in Fig. 1. The Pomeranian Province is situated along the southwest seaside on the Gulf of Gdańsk (southern Baltic Sea), and it is crossed by the lower Vistula River catchment area. The Pomeranian Province is highly diversified in terms of the relief, soil quality and forest cover. The area to the left of the Vistula River is part of the East Pomeranian Lakeland and, to a smaller extent, of the West Pomeranian Lakeland (Kondracki 1998). The region is characterised by the glacial landscape with numerous moraines and lakes. Forests cover a significant part of the land, even up to $75 \%$. Soils are dominated by light podzolic soils and by higher quality brown soils. Agricultural areas are small and punctuated with wasteland, hay meadows and pastures. In this part of the province, as many as 25 towns with human population between 3,800 and 460,000 inhabitants were studied.

Remaining towns were located east of the Vistula River in the area of Żuławy. The region is characterised by a depression with fertile soils supporting farmlands. Żuławy is located in the delta of the Vistula River at the mouth of the Baltic Sea. This area depression is small and constitutes about $2,460 \mathrm{~km}^{2}$. The Żuławy was formed from alluvial deposits accumulated during the recent 5,000 years, and forests cover a very small area ranging from $0 \%$ to $15 \%$. Fertile soils of Żuławy supply the production of cereals and rape (Kondracki 1998). In this part of the Pomeranian Province, there are many facilities for production, storing and processing of cereals, rape and root crops. Moreover, establishments involved in production of animal fodder are located in the region, contributing even further to its agricultural importance. In Żuławy and adjacent areas east of the Vistula River, eight towns were under study. Their population ranged from 3,900 in Nowy Staw to 40,000 inhabitants in Malbork.

In our research, we divided towns into two groups according to the dominating landscape type in the vicinity of towns. The groups were (1) towns localized among farmland and (2) towns localized in forested and water landscape (when cover by forests and water bodies was over $70 \%)$.

\section{Pigeons counting}

Counts of pigeons were carried out during autumn from the beginning of October through December. This is the best period for the inventory of feral pigeons, as only few of them breed at that time (Hetmański 2004). During these 


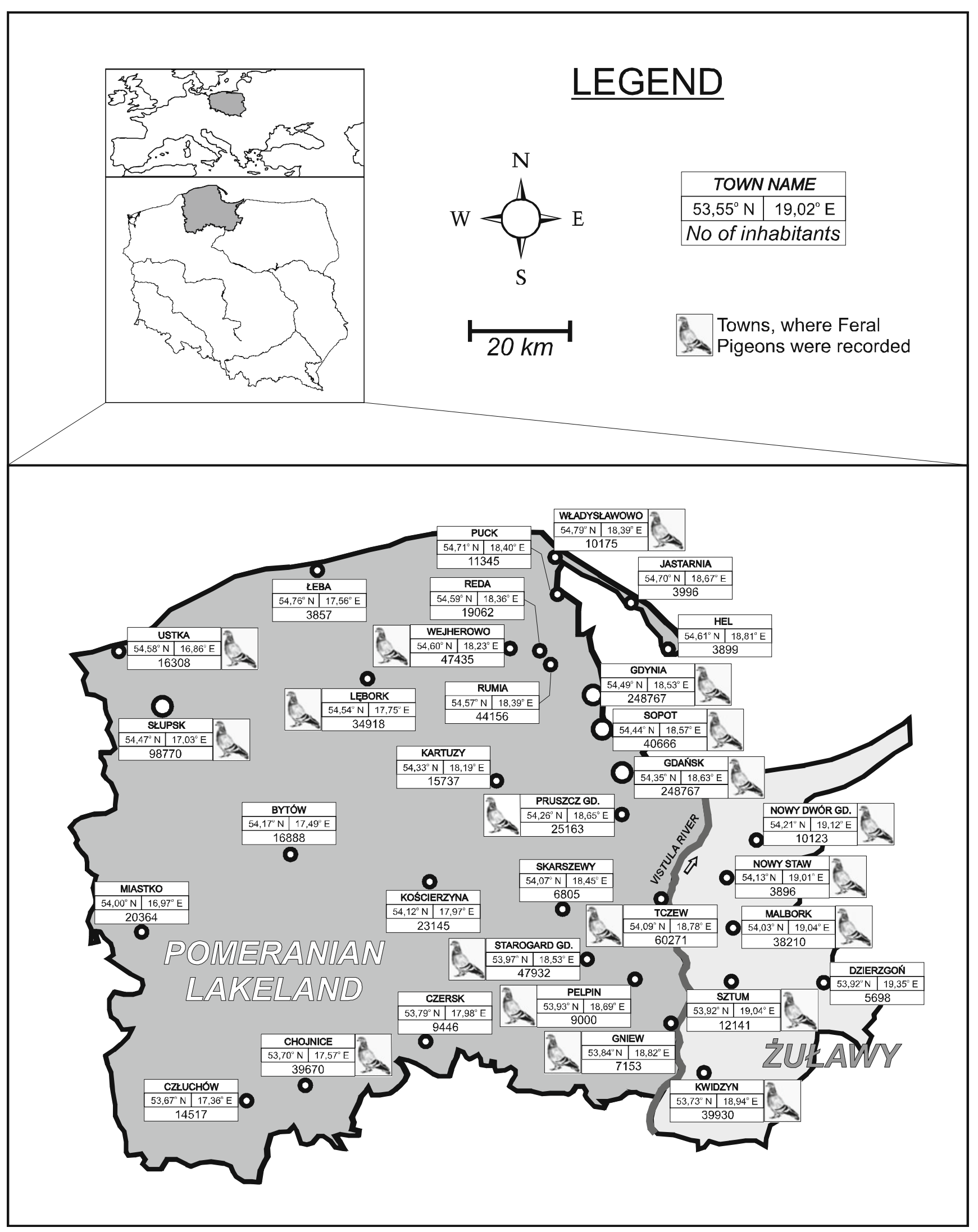

Fig. 1 Study area 
months, birds are outside the lofts, as they have to refill fat reserves (Rose et al. 2006a). Another reason why pigeons spend more time outside the loft during autumn is the limited access to the food resources in conjunction with the shortest foraging time (Hetmański 2004); thus, they gather around feeding grounds (Murton et al. 1972a, b). Moreover, Murton et al. (1972a) as well as Hetmański and Misiec (2008) showed that the tourists increase the food availability for pigeons in spring and summer but not during autumn.

Counts of pigeons were conducted from the morning until noon. We noticed that during the morning, the pigeons gathered at the feeding grounds and waited for food brought by humans. Giunchi et al. (2007) also conducted bird counts during the morning hours, and they have found that during this time period, most pigeons remained within the city.

We used a simple method of estimating the abundance of pigeons, which consisted primarily of counting birds attracted to the food (Sacchi et al. 2002) and counting birds departing to search for food over surrounding agricultural areas. Counters provided food at feeding sites where pigeons gathered. They used fine-grained cereals to extend the foraging time of pigeons arriving from the closest surroundings. In case the number of birds stabilized and no new birds arrived, the pigeons were counted three times. Several observers counted pigeons simultaneously in different places of the selected quarter of the town. They used bicycles to count pigeons in specified streets, courtyards, parks and squares. The census sites were randomly chosen, and survey effort was proportionally higher in larger towns. We surveyed $25 \%$ of the town's area. Birds moving to farmland were counted from dawn, before the birds foraging in the town were counted.

We did not apply the correction factor which some researchers used to incorporate in order to estimate the true population size of feral pigeons (Senar and Sol 1991; Senar 1996). Their correction factor was determined on the basis of the number of undetected marked birds in the surveyed area. They recommended multiplying the results of every quadrate count by 3.5. Giunchi et al. (2007) demonstrated, however, that detectability of feral pigeons differed in January and November; therefore, using a consistent correction factor of 3.5 is not an accurate solution for every time period.

Feral pigeons could be confounded with domestic pigeons, but longer observations and information from local inhabitants made it possible to determine the origin of birds and to notice the difference between domestic and feral pigeons.

We tested efficiency of used method, and to check how repeatable and comparable the results were, we used repeatability analysis. In 54 randomly selected parts of towns in the study area, pigeons were counted twice (with a gap of 10-14 days between counts). Repeatability of counts between sites was highly significant $\left(F_{1,53}=161.847, R^{2}=\right.$ 0.975, $P<0.0001)$.

\section{Statistical analysis}

The first analytical aim of the research was to describe the spatial aggregation in the abundance of the species by means of Moran's $I$ correlograms. A correlogram is a graph in which spatial autocorrelation values of a given parameter are plotted on the ordinate against distance classes among sampling points (Legendre 1993; Legendre and Legendre 1998). The spatial autocorrelation value at a given distance class indicates how predictable (positively or negatively) is the abundance of birds in a given point of the sampling framework. This probability is expressed as a function of the abundance of birds in a sampling point (town) located at the distance to $x$. Autocorrelation Moran's index typically varies between -1 and +1 with no significant values close to zero. Taking into account our sampling design, we considered eight distance classes chosen so that the number of towns' pairs was equal in each interval. We also manipulated with the distance classes and intervals in various ways, changing the distance from 10 to $40 \mathrm{~km}$ as well as altering the number of intervals, but this had no impact on the final results. To test the significance of the autocorrelation, we applied $P$ values based on the proportion of 500 Monte Carlo simulations performed in SAM statistical software (Rangel et al. 2006).

As we did not find evidence for spatial autocorrelation (see "Results" section), we used ordinary generalized linear model (Crawley 1993) with Poisson error distribution and log-link functions for testing which factors significantly influenced number of pigeons living in the studied areas. This method is recommended for counts data (Mac Nally 2000). Function parameters were estimated by Firth adjusted maximum likelihood method (Firth 1993; Jowaheer and Khan 2009) and corrected for over-dispersion. The explanatory variables were as follows: (1) landscape cover around the town (coded as binary variable: 0 , forest and water habitats; 1, farmland), (2) town area (square kilometre) and (3) number of inhabitants (log-transformed). Town area and number of inhabitants were highly positively correlated $\left(R_{\text {adj }}^{2}=0.62, P<0.001\right)$ and caused a problem of multicollinearity. To remove this effect, we performed simple regression between number of inhabitants and town area. Subsequently, we used the residual number of town inhabitants not explained by the town area in the later analyzes. Additionally, we introduced an interaction term between categorical variable (landscape type) and continuous explanatory variables (town area and residual number of 
inhabitants). The fit of the model was assessed by the corrected $R^{2}$ value (Mittlbock and Heinzl 2004) and the corrected Akaike information criterion AICc (Hurvich and Tsai 1989). We used JMP 8 statistical software during GLM analyses. As the distribution of number of pigeons in towns was highly skewed, the means given in text are corrected by logarithmical transformation.

\section{Results}

Feral pigeons were observed in 19 out of $33(57.6 \%)$ towns under study. More than 1,000 individuals were noted only in Gdańsk, Gdynia and Słupsk. Typically, feral pigeons were not present in smaller towns (less than 1,000 inhabitants), but they were also absent in Rumia with 40,000 inhabitants and in Starogard Gdański with 50,000 inhabitants; only 25 individuals were noted.

In the largest towns of the Pomeranian Province, feral pigeons were concentrated mainly in central quarters. In smaller towns, they were noted in central parts or in areas with blocks of flats and, surprisingly, in the suburbs. For example, in Nowy Staw, pigeons concentrated in the old market square. In Tczew and Kwidzyn, flocks were more abundant in areas with blocks of flats than in the centre. In Władysławowo, the only colony inhabited a tower at the edge of the town.

We did not find any evidence for spatial autocorrelation in abundance of the species in studied towns (Fig. 2). Moran's $I$ coefficients were always close to zero at all distance intervals (Fig. 2).

The statistical analysis indicated that the best-suited model contained all the effects (AICs $=3,893.3$ ) and explained $86 \%$ of variance. All models with reduced number of explanatory variables had higher AICc. The number of pigeons was positively correlated with the area of the town (Table 1 and Fig. 3a), and it was significantly

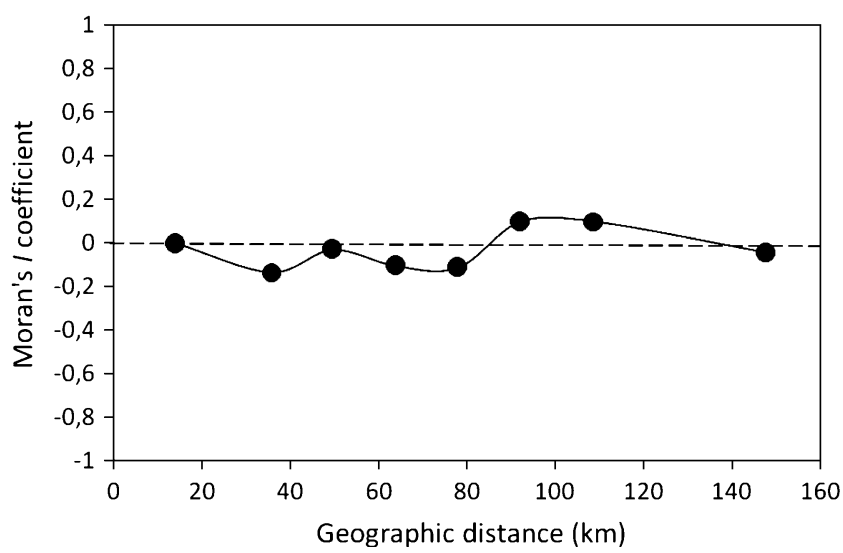

Fig. 2 Spatial correlogram of abundance of pigeons in towns. The dashed line indicates the expected values under the null hypothesis of absence of autocorrelation
Table 1 Results of GLM model with Poisson error and log-link function

\begin{tabular}{llrr}
\hline Effect & $d f$ & \multicolumn{1}{c}{$\chi^{2}$} & \multicolumn{1}{l}{$P$} \\
\hline Town area & 1 & 18.730 & $<0.001$ \\
Number of inhabitants & 1 & 2.168 & 0.141 \\
Landscape type & 1 & 13.338 & $<0.001$ \\
Landscape type $\times$ town area & 1 & 2.493 & 0.114 \\
Landscape type $\times$ number of inhabitants & 1 & 5.091 & 0.024 \\
\hline
\end{tabular}

higher in towns localized in agricultural landscape (mean \pm SE, 338.7 \pm 1.3 ) than in towns surrounded by forests (mean \pm SE, $11.2 \pm 1.9$; mostly because in a few latter towns, pigeons were absent). We found significant effect of interactions between type of a landscape surrounding a town and residual number of inhabitants on the abundance of pigeons (Table 1). In towns surrounded by forests and waters, the number of inhabitants was positively correlated with the number of pigeons, whereas in towns surrounded by the agricultural
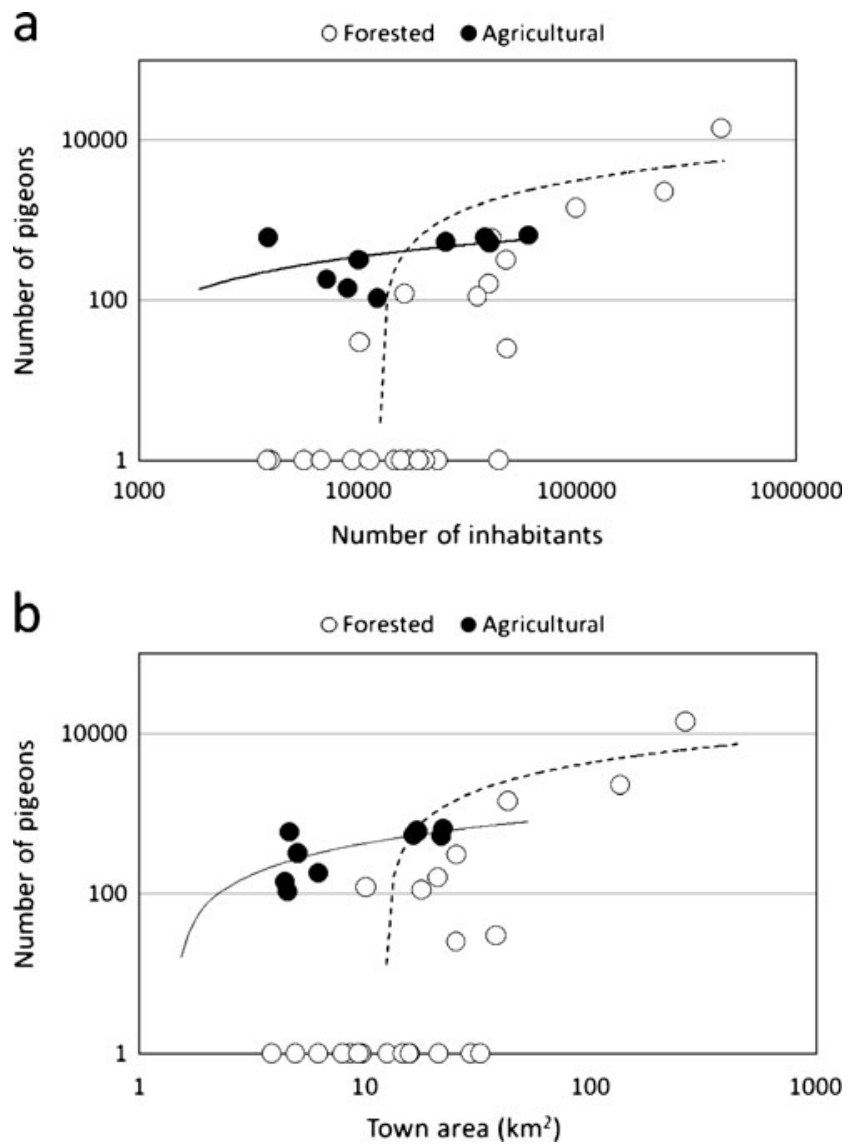

Fig. 3 Effect of $\mathbf{a}$ town area and $\mathbf{b}$ number of inhabitants on number of feral pigeon Columba livia var. domestica in towns of northern Poland surrounded by forested (white circles and dotted line) and agricultural landscape (black circles and solid line). Logarithmic function is fitted 
land, the relationship was absent (significant difference in the regression slopes, Fig. 3b).

\section{Discussion}

After World War II, the population of feral pigeons increased in towns where they were previously observed. In the same time, they colonised new towns in Europe (Johnston and Janiga 1995). Some studies conducted in towns of northern Poland showed that three towns were colonised in the 1970s: Koszalin (Górski and Górska 1979), Słupsk (Górski 1982) and Olsztyn (Okulewicz 1971). The densities of birds recorded at that time were very low, approximately on the level of one pair/10 ha. Currently, pigeon populations in these towns comprise more than 1,000 individuals (personal observation). In some larger towns of Europe, pigeon populations began to stabilize already in the 1980s (Konstantinov et al. 1996). The present study in 33 towns of the Pomeranian Province shows that the colonisation of towns by pigeons advances and constitutes a part of a long-term process. The lack of spatial autocorrelation indicates that each town with pigeons may be considered as an independent local population. Since pigeons are rather reluctant to leave their natal area (Hetmański 2007), it is possible that the local factors (e.g. availability of refuse or landscape around to the natal town) maybe a key factor affecting local population dynamics (Hetmański and Barkowska 2008).

Our results suggest that number of inhabitants and type of habitats surrounding towns (i.e. food resources for pigeons) are important factors limiting the local population size of pigeons in towns. Towns surrounded by farmland had significantly higher numbers of feral pigeons than towns surrounded mostly by forests and lakes. This implies that food resources in small and medium towns surrounded by forests or lakes are insufficient to be colonised by pigeons. For instance, in Starogard Gdański (localized in an arboreal landscape) with 50,000 inhabitants, local population of pigeons comprised only 25 individuals. In Lębork $(35,000$ inhabitants), pigeon population was established as late as in 2003 as a result of the introduction of pigeons from Słupsk by pigeon-fanciers from Lębork. The present population in Lębork consists of over 110 birds, as compared with 25 individuals in 2003 . The increase in this population was possible due to abundant supplemental feeding in the centre of the town. However, the above explanation should be treated with caution because we did not quantify directly food resources within towns. It could be extremely difficult as the food resources are patchily distributed and often changes location (depending on people leaving food or refuse), and it was impossible to collect this information in this study. Further study should quantify such resources and estimate their role in shaping local pigeons densities within towns.

The study conducted in northern Poland shows that feral pigeons can use food resources not only in urbanised areas but also in their surroundings. Some birds chose to forage in the streets and yards (Hetmański and Jarosiewicz 2008; Hetmański and Misiec 2008), whereas others rely on the recourses outside towns (Janiga 1987). Rose et al. (2006a, b) used the GPS method that allowed them to record and follow commuting flights to the arable fields. They found that pigeons used different individual foraging strategies even within the same population. Females commuted further than males, and the foraging activity depended on the breeding state and season. Birds are flexible enough to adapt to different urban environments. Consequently, when attempting to manage pigeon populations in towns, the habitats surrounding these towns should be considered, as shown for corvids (Jerzak et al. 2005). The corvids are also the best reference points showing importance of agricultural land around towns for foraging.

Another explanation for strong relationship between number of pigeons and number of humans in towns surrounded by forest as well as lower number of pigeons in these towns is that pigeons may be reluctant to forage in forested landscape. Forests are inhabited by many predators, as e.g. goshawk Accipiter gentilis that frequently prey upon different species of pigeons. It does not necessary mean that predation rate is high in towns localized in forested landscape, but even the presence of predators may change behaviour of the potential prey (non-lethal effect of predators; Lima 2009). What is more, forests may constitute a behavioural barrier for pigeons by increasing the cost of finding food as was shown for other species (Skórka et al. 2009).

In our study, we found that abundance of pigeons was positively related to town's area and independent from the surrounding landscape type. The area-population abundance relationship is a well-documented ecological phenomenon in many taxa (Prugh et al. 2008). This has important practical consequence, indicating that the greatest number of humanpigeons conflicts arises in larger towns. Simultaneously, in small towns, controlling number of pigeons seems to be much easier.

Obviously, in our study, we did not include other factors potentially affecting pigeon abundance in towns. One of such variable may be the age and building structure of a town. Speirs et al. (1970) found that pigeon populations can be larger in smaller but older towns than in larger and younger towns. The present results partially confirm this observation as no pigeons were found in towns without a distinct centre with old buildings, such as Rumia and Reda, where residential architecture predominates. Buildings of this kind with allotments gardens are not readily colonised 
by pigeons (Luniak 1980). Instead, pigeons showed preference for central parts of towns mainly with old buildings mostly those built before the war (Sacchi et al. 2002). In large towns in our study area, such as Shupsk and Gdynia, pigeons concentrated mainly in their centres where old buildings can be found. However, in small towns, this was not the rule. For example, in Tczew, more birds were observed in the area with blocks of flats than in the old town. A similar situation was noted in Olsztyn, where the highest densities of pigeons were found in the quarter with blocks of flats, rather than in the centre of the town (Nowakowski et al. 2006). In Starogard Gdański, on the contrary, pigeons occurred in the centre of the town, and they were absent from blocks of flats. Thus, it seems that there is no general pattern in occupation of various parts of towns by pigeons.

Availability of nesting sites is the other factor that could affect population size of the feral pigeons but was not included in this study. However, we think that nesting sites cannot be a limiting factor for this species. Feral pigeon is a species of remarkable nest site choice plasticity. It breeds in cavities, bridges, on balconies, windowsills and many others places. Even in areas of high pigeon density, we often found many potential breeding sites for this species, but not occupied (unpublished observations).

Moreover, it must be admitted that our model explained considerable part of the variation in the dataset, which indicates that we included in our study all key factors affecting local population sizes of the feral pigeons in northern Poland.

\section{Management recommendations}

Our study showed that both town area and number of human inhabitants positively influence population sizes of the feral pigeons. Haag-Wackernagel (1993) stated that population size of pigeons foraging within the city limits can be quite easily controlled by reducing food resources delivered by humans. We think it is the case mostly in towns surrounded by forests and wetlands. In these towns, reduction of the abundance of food resources may be the most effective way to control pigeon abundance because the birds cannot find alternative food sources.

We think that future studies should focus on methods of effective removal of pigeons from the parts of towns where they cause the largest problems. Moreover, more studies on habitat selection and (micro)habitat use within towns by the species are crucial.

Acknowledgements The final analysis of the data was supported by a small grant project from the City of Poznań (RoM. III/3420-56/10). We thank Tim H. Sparks for linguistic corrections.
Open Access This article is distributed under the terms of the Creative Commons Attribution Noncommercial License which permits any noncommercial use, distribution, and reproduction in any medium, provided the original author(s) and source are credited.

\section{References}

Baldaccini N, Giunchi D, Mongini E, Ragionieri L (2000) Foraging flights of wild rock doves (Columba L. livia): a spatio-temporal analysis. Ital J Zool 67:371-377

Barbieri F, De Andreis C (1991) Indagine sulla presenza die colombi (Columba livia forma domestica) nel centro storico di Pavia e nell'Oltrepò. Suppl Ric Biol Selvaggina 17:195-198

Bassi M, Chiatante D (1976) The role of pigeon excrement in stone biodeterioration. Int Biodet Bull 12:73-79

Crawley MJ (1993) GLIM for ecologists. Blackwell Science, Oxford

Firth D (1993) Bias reduction of maximum likelihood estimates. Biometrika 80:27-38

Fuller RA, Warren PH, Armsworth PR, Barbosa O, Gaston KJ (2008) Garden bird feeding predicts the structure of urban avian assemblages. Diversity Distrib 14:131-137

Giunchi D, Gaggini V, Baldaccini NE (2007) Distance sampling as an effective method for monitoring feral pigeon (Columba livia $\mathrm{f}$. domestica) urban populations. Urban Ecosyst 10:397-412

Górski W (1982) The breeding birds of Słupsk and its suburban areas. Acta Zool Cracov 26:31-93

Górski W, Górska E (1979) Quantitative investigations on the breeding avifauna of Poznań and Koszalin in 1972. Acta Ornithol 16:513-533

Haag-Wackernagel D (1993) Street pigeons in Basel. Nature 361:200

Haag-Wackernagel D (2000) Behavioural responses of the feral pigeon (Columbidae) to deterring systems. Folia Zool 49:101-114

Haag-Wackernagel D, Moch H (2004) Health hazards posed by feral pigeons. J Infect 48:307-313

Hetmański T (2004) Timing of breeding in the feral pigeon Columba livia f. domestica in Słupsk (NW Poland). Acta Ornithol 39:105-110

Hetmański T (2007) Dispersion asymmetry within a feral pigeon Columba livia population. Acta Ornithol 42:23-31

Hetmański T, Barkowska M (2008) Breeding parameters and recruitment in feral pigeons Columba livia f. domestica. Acta Ornithol 43:159-166

Hetmański T, Jarosiewicz A (2008) Plumage polymorphism and breeding parameters of various feral pigeon (Columba livia $\mathrm{Gm}$.) morphs in urban area (Gdańsk, N Poland). Pol J Ecol 56:683-691

Hetmański T, Misiec K (2008) Wyniki badań ankietowych struktury ludności dokarmiającej gołębie miejskie Columba livia w miastach Pomorza (Results of survey on structure of people feeding feral pigeons Columba livia in the towns of Pomerania). In: Indykiewicz P, Jerzak L, Barczak T (eds) Fauna miast: ochronić różnorodność biotyczną w miastach, Bydgoszcz: SAR "Pomorze"., pp 629-634 [In Polish: English Abstract]

Hurvich CM, Tsai C-L (1989) Regression and time series model selection in small samples. Biometrika 76:297-307

Janiga M (1987) Seasonal aspects of intensity and course of daily translocations of pigeons (Columba livia f. domestica) for food from Bratislava to its surroundings. Acta Fac Rerum Nat Univ Comenianae 32:47-59

Jerzak L, Kavanagh B, Tryjanowski P (eds) (2005) Corvids of Poland. Bogucki Wydawnictwo Naukowe, Poznań

Johnston R, Janiga M (1995) Feral pigeon. Oxford University Press

Jokimäki J, Suhonen J (1998) Distribution and habitat selection of wintering birds in urban environments. Land Urban Plann $34: 253-263$ 
Jokimäki J, Kaisanlathi-Jokimäki ML (2003) Spatial similarity of urban bird communities: a multiscale approach. J Biogeogr 30:1183-1193

Jowaheer V, Khan NAM (2009) Estimating regression effects in com Poisson generalized model. Wood Acad Sci Eng Technol 53:1046-1050

Kondracki J (1998) Geografia regionalna Polski. PWN, Warszawa [In Polish]

Konstantinov VM, Nowicki W, Pichurin AG (1996) Recent changes in the avifauna of cities in European Russia and Eastern Polandresults of a questionnaire. Acta Ornithol 31:59-66

Legendre P (1993) Spatial autocorrelation: trouble or new paradigm? Ecology 74:1659-1673

Legendre P, Legendre L (1998) Numerical ecology. Elsevier, Amsterdam

Lima SL (2009) Predators and the breeding bird: behavioral and reproductive flexibility under the risk of predation. Biological Reviews 84:485-513

Luniak M (1980) Birds of allotment gardens in Warsaw. Acta Ornithol 17:297-320

Magnino S, Haag-Wackernagel D, Geigenfeind I, Helmecke S, Dovč A, Prukner-Radovčić E, Residbegović E, Ilieski V, Laroucau K, Donati M, Martinov S, Kaleta EF (2009) Chlamydial infections in feral pigeons in Europe: review of data and focus on public health implications. Vet Microbiol 135:54-67

Marzluff JM, Bowman R, Donnelly R (2001) Avian ecology and conservation in urbanizing world. Kluwer Academic Publishers, Boston

Mac Nally R (2000) Regression and model-building in conservation biology, biogeography and ecology: the distinction betweenand reconciliation of - 'predictive' and 'explanatory' models. Biodivers Conserv 9:655-671

Mittlbock M, Heinzl H (2004) Pseudo R-squared measures for generalized linear models. Proceedings of the 1st European Workshop on the Assessment of Diagnostic Performance, Milan, Italy, pp 71-80

Murton RK, Coombs CFB, Thearle RJP (1972a) Ecological studies of the feral pigeon Columba livia var. II. Flock behaviour and social organization. J Appl Ecol 9:875-879

Murton RK, Thearle RJP, Thompson J (1972b) Ecological studies of the feral pigeon Columba livia var. I. Population, breeding biology and methods of control. J Appl Ecol 9:835-874

Nowakowski JJ, Dulisz B, Lewandowski K (2006) Birds of Olsztyn. ElSet, Olsztyn
Okulewicz J (1971) Birds of Olsztyn and its victinity. Acta Ornithol 13:127-172

Prugh LR, Hodges KE, Sinclair RE, Brashares JS (2008) Effect of habitat area and isolation on fragmented animal populations. Proc Natl Acad Sci USA 105:20770-20775

Rangel TFLVB, Diniz-Filho JAF, Bini LM (2006) Towards an integrated computational tool for spatial analysis in macroecology and biogeography. Global Ecol Biogeogr $15: 321-327$

Robb GN, McDonald RA, Chamberlain DE, Reynolds SJ, Harrison THE, Bearhop S (2008) Winter feeding of birds increases productivity in the subsequent breeding season. Biol Lett 4:220-223

Rose E, Nagel P, Haag-Wackernagel D (2006a) Spatio-temporal use of the urban habitat by feral pigeons (Columba livia). Behav Ecol Sociobiol 60:242-254

Rose E, Haag-Wackernagel D, Nagel P (2006b) Practical use of GPSlocalization of feral pigeons Columba livia in the urban environment. Ibis 148:231-239

Sacchi R, Gentilli A, Razzetti E, Barbieri F (2002) Effects of building features on density and flock distribution on feral pigeons Columba livia var. domestica in an urban environment. Can $\mathrm{J}$ Zool 80:48-54

Senar JC (1996) Bird census techniques for the urban habitat: a review. In: Alleva E, Baldaccini NE, Fortuna P, Mantovani A (eds) Controllo delle popolazion ornitiche sinantropiche: problemi e prospettive. Istituto Superiore di Sanità, Rome, pp 36-44 [in Italian]

Senar JC, Sol D (1991) Censo de Palomas Columba livia var. de la ciudad de Barcelona: aplicación del muestreo estratificado con factor de corrección. Butlleti del Grup Catala d'Anellament 8:19 24 [in Italian]

Skórka P, Lenda M, Martyka R, Tworek S (2009) The use of optimal foraging and metapopulation theories to predict animal movement and foraging decisions in mobile animals in heterogeneous landscapes. Land Ecol 24:599-609

Sol D, Senar JC (1995) Urban pigeon populations: stability, home range, and the effect of removing individuals. Can J Zool 73:1154-1160

Speirs MJ, Markle G, Tozer RG (1970) Populations of birds in urban habitats, Ontario County, 1969. Ont Field Biol 24:1-12

Vlahović K, Matica B, Bata I, Pavlak M, Pavičić Ž, Popović M, Nejedli S, Dovč A (2004) Campylobacter, Salmonella and Chlamydia in free-living birds of Croatia. Eur J Wildl Res 50:127-132 